\section{Organic Fertilizers for Greenhouse Tomatoes: Productivity and Substrate Microbiology}

\author{
Zhengli Zhai \\ Centre for Agricultural Resources Research, Institute of Genetics and \\ Developmental Biology, Chinese Academy of Sciences, Shijiazhuang \\ 050021, China Graduate University of the Chinese Academy of Sciences, \\ Beijing 100049, China \\ David L. Ehret ${ }^{1}$, Tom Forge, Tom Helmer, and Wei Lin \\ Agriculture and Agri-Food Canada, Pacific Agri-Food Research Centre, \\ P.O. Box 1000, Agassiz, British Columbia Canada V0M 1 A0
}

\section{Martine Dorais \\ Agriculture and Agri-Food Canada, Horticultural Research Centre, Laval University, Quebec, Canada GIV $0 A 6$}

\section{Athanasios P. Papadopoulos \\ Agriculture and Agri-Food Canada, Greenhouse and Processing Crops Research Centre, Harrow, Ontario, Canada NOR 1G0}

Additional index words. compost, spent mushroom substrate, composted yard waste, swine compost, organic liquid fertilizer, fish fertilizer, nematodes, FDA, EcoLog

\begin{abstract}
Organic fertilizer regimens consisting of combinations of composts (yard waste, swine manure, or spent mushroom substrate) and liquid fertilizers (fish- or plant-based) were evaluated against conventional hydroponic fertilizers in two experiments with greenhouse tomatoes grown in peat-based substrate. Crop yield and fruit quality were evaluated and several assays of substrate microbial activity and community profiles (fluorescein diacetate analysis and EcoLog, values, nematode counts) were conducted. Crops grown in $\mathbf{2 0 \%}$ to $\mathbf{4 0 \%}$ compost (yard waste or yard waste plus swine manure) plus a continuously applied liquid source of organic potassium (K), calcium (Ca), magnesium $(\mathrm{Mg})$, and sulphate $\left(\mathrm{SO}_{4}\right)$ could not be sustained more than 1 month before nutrient deficiencies became visible. Supplementation with a nitrogen $(\mathrm{N})$ - and phosphorus (P)containing plant-based liquid fertilizer at the point when plant deficiencies became apparent subsequently produced yields $\approx \mathbf{8 0} \%$ that of the hydroponic control. In a second experiment, the proportion of mushroom or yard waste compost was increased to $50 \%$ of the mix, and liquid delivery of $\mathrm{K}, \mathrm{Ca}, \mathrm{Mg}$ and $\mathrm{SO}_{4}$ plus either plant-based or fish-based $\mathrm{N}$ and P-containing liquid feeds was started at the date of transplanting. In this case, organic yields equal to that of the hydroponic control $(8.5 \mathrm{~kg} / \mathrm{plant})$ were observed in some treatments. The most productive organic treatment was the mushroom compost supplemented with a low concentration of the plant-based liquid fertilizer. In general, organic tomatoes had a lower postharvest decay index (better shelf life) than did the hydroponic controls, possibly as an indirect consequence of overall reduced yield in those treatments. High concentrations of both organic liquid feeds resulted in lower yields as a result of treatment-induced fusarium crown and root rot. In contrast to some previous studies, those treatments showing fusarium crown and root rot also had the highest gross microbial activity. Measures of gross microbial activity and numbers of microbivorous nematodes were higher (average of $37 \%$ and 6.7 times, respectively) in compost/organic feed treatments than in the hydroponic control. Community physiological profiles of the bacterial populations, on the other hand, did not differ between organic and hydroponic treatments. Nematode populations were significantly correlated with gross microbial activity in the organic treatments.
\end{abstract}

\footnotetext{
Received for publication 9 Jan. 2009. Accepted for publication 19 Mar. 2009.

We acknowledge the financial support of the BC Greenhouse Growers' Association Research Council and the Matching Investment Initiative of Agriculture and Agri-Food Canada and the generous in-kind support of All Seasons Mushrooms, Great Pacific Bioproducts, Technaflora Plant Products, and the Vancouver composting facility.

We also gratefully acknowledge the China Scholarship Council. The technical assistance of Glenn Block is appreciated.

Use of trade names does not imply endorsement of the products named nor criticism of similar ones not named.

${ }^{1}$ To whom reprint requests should be addressed; e-mail david.ehret@agr.gc.ca.
}

Organic production methods encourage the use of organic waste materials as substitutes for chemical fertilizers. This may be an effective way to use the high volumes of urban yard waste and waste organic materials emanating from dairy, poultry, swine, or greenhouse operations and is therefore of potentially significant environmental value (Cheng et al., 2004; Mazuela et al., 2005). Chong (Chong, 2005; Chong and Purvis, 2004) has developed recommendations for use of a variety of waste and compost products in the nursery industry, some of which could be applied to organic production settings. Amending soil or potting media with some organic wastes can improve soil physical properties with increased porosity and waterholding capacity as well as improved biological characteristics (Celik et al., 2004; Lee et al., 2004; Marinari et al., 2000).

Although a good deal of research has been conducted on the use of organic waste in field vegetable production (Ball et al., 2000; Smith et al., 2001), relatively little has been done in greenhouse vegetable production. A full range of organic wastes, from municipal wastes to agricultural residues, could potentially be used as compost feedstock, depending on local availability and country legislation for organic products. For example, composts produced from several different types of agricultural residues may be suitable materials for container media or in field soils (Martínez et al., 2005). Rippy et al. (2004) found that several combinations of vermicompost plus organic liquid feeds produced yields similar to those of conventional hydroponic treatments.

Liquid fertilizers formulated for organic agriculture are often made from organic wastes and can be applied as a foliar spray or through drip irrigation lines as an alternative to chemical fertilizer. Cheng et al. (2004) used a greenhouse tomato crop to recover part of the nutrients from swine wastewater to reduce the risk of nitrogen $(\mathrm{N})$ and phosphorus (P) losses to the environment. This has proven to be a feasible and promising alternative technology for converting swine wastewater into value-added product. Liedl et al. (2004) found that liquid effluent of digested poultry litter appeared to function as well as a commercial hydroponic fertilizer for tomatoes after balancing the forms of $\mathrm{N}\left(\mathrm{NO}_{3} / \mathrm{NH}_{4}\right)$ and supplementing with $\mathrm{Ca}\left(\mathrm{NO}_{3}\right)_{2}$ and $\mathrm{MgSO}_{4}$. Abbasi et al. (2004) used fish emulsion in a peat mix to grow radish and cucumber seedlings. The result suggested that fish emulsion had both nutritive value for plant growth as well as diseasesuppressive properties and thus might be useful for organic or conventional transplant production.

Organic residues act not only as a source of nutrients and organic matter, but also may increase the size, biodiversity, and activity of the microbial populations in soil, thereby influencing structure, nutrient turnover, and many other related physical, chemical, and biological parameters (Albiach et al., 2000). Organic residues can differ substantially in 
terms of their effects on soil or substrate microbial activity and derived benefits like disease suppression (Borrero et al., 2004; Hoitink and Boehm, 1999; Kannangara et al., 2000; Litterick et al., 2004; Noble and Coventry, 2005; Ntougias et al., 2008; Zinati, 2005). For example, Martínez et al. (2005) estimated microbial activity by fluorescein diacetate analysis (FDA) and found that microbial biomass was higher in composted cork thin waste mixed with rice hulls than in peat used in soilless strawberry production. Relatively little is known of the relationships among organic waste amendments, microbial activity, and overall production in the context of organic practices, especially with respect to containerized greenhouse production. Furthermore, to our knowledge, there is no information available comparing the substrate microbial activity of organic and hydroponic systems.

The objective of this study was to develop methods of producing organic greenhouse tomato plants, which show the long-term health and productivity expected of hydroponic plants. The emphasis was on using fertilizers and byproduct organic materials that are available in enough supply to be used in large commercial greenhouse operations and in keeping with the organic philosophy, locally produced. The effects of composts and fertilizers on substrate biological activity, and the relationships between biological activity and productivity, were also determined.

\section{Materials and Methods}

General crop information. Two experiments were conducted in 2008 at the Pacific Agri-Food Research Center, Agassiz, BC, Canada (lat. $49^{\circ} 15^{\prime} \mathrm{N}$, long. $121^{\circ} 46^{\prime} \mathrm{W}$ ). The first experiment involved a beefsteak cultivar and the second used a cluster cultivar. In each, seed was sown into 4-inch (10$\mathrm{cm}$ ) pots filled with a peat/perlite (4:1 ratio by volume) mixture and transplanted at a density of 2.75 plants $/ \mathrm{m}^{2}$ into a $75-\mathrm{m}^{2}\left(64-\mathrm{m}^{2}\right.$ growing area) venlo-style greenhouse compartment where the trials were conducted. In all experiments, the peatmoss was Sungrow OMRI white course peat (Allies Wholesale, Abbotsford, BC, Canada) and the perlite (TerraLink Horticulture Inc., Abbotsford, $\mathrm{BC}$, Canada) was medium grade. The greenhouse environment was computer-controlled (Argus Controls, White Rock, BC, Canada). Greenhouse temperature set points were 19 to $21{ }^{\circ} \mathrm{C}$ during the day and 17 to $19^{\circ} \mathrm{C}$ at night. Relative humidity was maintained between $40 \%$ and $80 \%$ day and $35 \%$ and $70 \%$ night using ventilation and misting throughout the growing season. Plants were irrigated (fertigated) with fertilizer solution multiple times each day based on light sum, which ranged from 250 to $500 \mathrm{Wm}^{-2}$ (irrigation frequency was low early in the trials to minimize leaching but increased as the plants grew). Each irrigation event delivered $\approx 132 \mathrm{~mL}$ of nutrient feed to each plant over $1 \mathrm{~min}$ through two pressure-compensated drippers $\left(4 \mathrm{~L} \cdot \mathrm{h}^{-1}\right.$ or $\left.66 \mathrm{~mL} \cdot \mathrm{min}^{-1}\right)$. Leaching ranged from $10 \%$ to $30 \%$. Nightly irrigations occurred every 4 to $6 \mathrm{~h}$. Plants were pruned and trained according to commercial production practices (Anonymous, 1996) except that stem density was not modified through the growing season. Fruit were harvested three times per week.

Expt. 1. Seeds of the beefsteak cultivar Rapsodie (Rogers/Syngenta Seeds, Boise, ID) and the rootstock, Maxifort (deRuiter Seeds, Bergschenhoek, The Netherlands) were sown on 2 Jan. Maxifort is resistant to Verticillum sp., Fusarium oxysporum races 1 and 2, Fusarium oxysporum $f_{s p}$. Radicislycopersici (crown rot), most common species of plant-parasitic nematodes, and Pyrenochaeta lycopersici (corky root). Grafting took place from 22 to $25 \mathrm{Jan}$. Plants were transplanted into $15-\mathrm{L}$ pots $(\mathrm{h}=23 \mathrm{~cm}, \mathrm{w}=31$ $\mathrm{cm}$ at the top) (one plant per pot) on $26 \mathrm{Feb}$. in the experimental greenhouse compartment.

Two composts were compared in this experiment: yard waste (YW) compost and swine $(\mathrm{Sw})$ compost. Yard waste compost was produced by the City of Vancouver Green Waste Recycling Program. It is a Class A compost produced according to British Columbia's Organic Matter Recycling Regulation (Government of British Columbia,
2007) using feedstocks consisting solely of yard waste and lawn clippings. Certified organic swine compost was obtained from Gelderman Farms, Abbotsford, BC, Canada. Mineral analysis of the composts is detailed in Table 1. Four substrates or combinations of substrate were compared, all with a base of peat/perlite: 1) peat/perlite (control); 2) 20\% yard waste compost; 3) $40 \%$ yard waste compost; and 4) $20 \%$ swine compost plus $20 \%$ yard waste compost. All mixes were blended on a volume/volume basis.

Three liquid feeds were also tested: 1) a standard hydroponic tomato feed; 2) organic feed A consisting of potassium $(\mathrm{K})$, calcium (Ca), magnesium $(\mathrm{Mg})$, and sulphate $\left(\mathrm{SO}_{4}\right)$ derived from organic potash, calpril, and dolopril (Terralink Horticulture Inc., Abbotsford, BC, Canada) at concentrations similar to the standard hydroponic feed; and 3 ) organic feed B, consisting of organic feed A supplemented with a blend of commercially available liquid products certified by OMRI (Organic Materials Review Institute, Eugene, OR) as a source of $\mathrm{N}$ (Table 2). The blend consisted of PuraVida Grow (6-4-4), PuraVida Bloom (2-6-6), and Thrive-Alive (1-1-1), all plant-based products from Technaflora

Table 1. Chemical characteristics of the composts used in the experiments.

\begin{tabular}{|c|c|c|c|c|}
\hline$\overline{\text { Characteristic }^{z}}$ & Units & Yard waste & Swine & $\overline{\text { Mushroom }}$ \\
\hline Electrical conductivity & $\left(\mathrm{mS} \cdot \mathrm{cm}^{-1}\right)$ & 2.78 & 13.4 & 2.92 \\
\hline $\mathrm{pH}$ & & 7.6 & 5.7 & 7.36 \\
\hline Nitrogen & Percent total & 1.97 & 2.38 & 2.31 \\
\hline Phosphorus & Percent total & 0.26 & 1.09 & 0.93 \\
\hline Total carbon & Percent total & 18.3 & 31.1 & 29.4 \\
\hline $\mathrm{C} / \mathrm{N}$ & & $9: 1$ & $13: 1$ & $14: 1$ \\
\hline Potassium & Percent total & 0.97 & 3.27 & 1.4 \\
\hline Calcium & Percent total & 1.73 & 1.3 & 11.02 \\
\hline Magnesium & Percent total & 0.41 & 0.48 & 0.53 \\
\hline Sodium & Percent total & 0.05 & 0.84 & 0.24 \\
\hline Ammonium & ppm & 362 & 268 & 679 \\
\hline Iron & ppm & 9,756 & 624 & 1,204 \\
\hline Zinc & ppm & 148 & 372 & 191 \\
\hline Copper & ppm & 51 & 43 & 139 \\
\hline Molybdenum & ppm & $<2$ & $<2$ & 3.85 \\
\hline
\end{tabular}

${ }^{\mathrm{z}}$ Values were obtained from dried compost before mixing into the substrate blends.

Table 2. Composition of the liquid feeds used in the experiments.

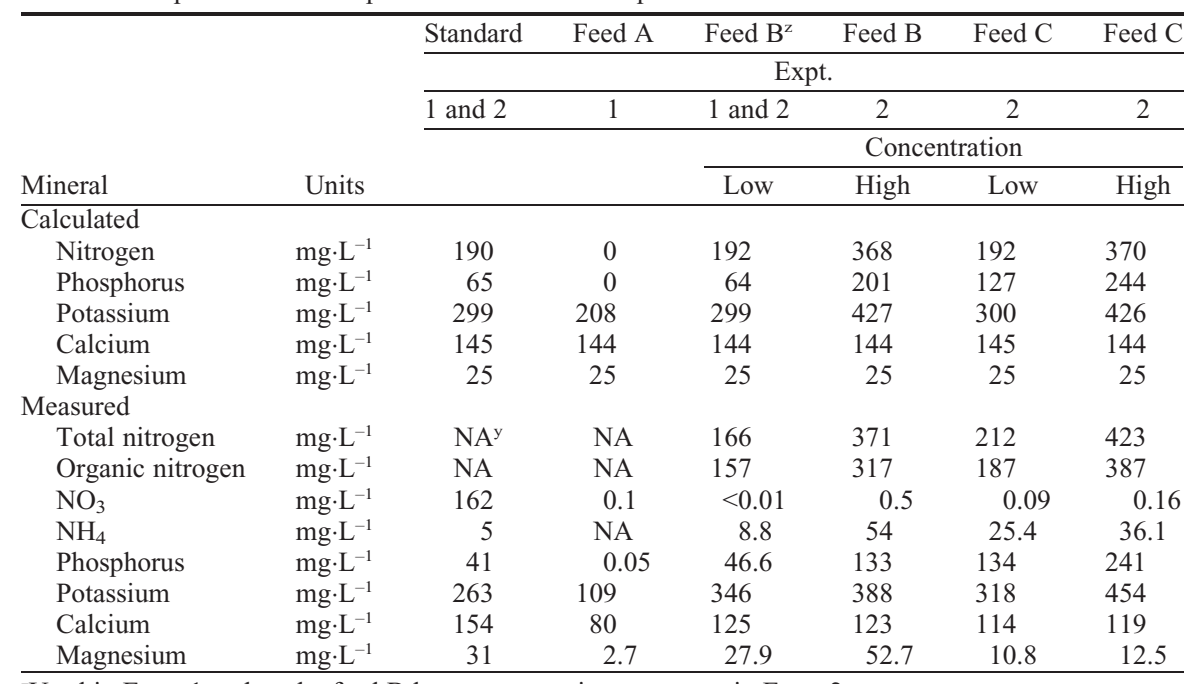

${ }^{\mathrm{z}}$ Used in Expt. 1 and as the feed B low concentration treatment in Expt. 2.

yot available. 
Plant Products Ltd. (Port Coquitlam, BC, Canada). These three products were added in a ratio of 3.0:0.35:0.50 (Grow:Bloom: Thrive Alive) to supply organic $\mathrm{N}$ at concentrations similar to that of the inorganic $\mathrm{N}$ (target $\mathrm{NO}_{3}$ plus $\mathrm{NH}_{4}$ of $190 \mathrm{mg} \cdot \mathrm{L}^{-1}$ ) in the standard hydroponic feed. Note that organic feed A did not include a $\mathrm{N}$ and $\mathrm{P}$ source; this allowed us to determine how long the composts would supply $\mathrm{N}$ and $\mathrm{P}$ to the plant before becoming depleted while providing most other essential nutrients. Leaching of nutrients from the pots was minimized by allowing only minimal overdrain and by collecting the excess using saucers for the first $46 \mathrm{~d}$ of the experiment. Plants receiving organic feed B initially received organic feed A until the early stages of $\mathrm{N}$ deficiencies were evident based on visual observation (26 Mar. 2008), at which time they were switched. Using this approach, the plants would rely on composts as a source of $\mathrm{N}$ for as long as possible before it became necessary to supplement with liquid sources of N. Proprietary liquid organic fertilizers are relatively expensive and will potentially plug drippers so it is practical to delay their use. There were a total of seven treatments (Table 3). The $\mathrm{pH}$ of all treatments was adjusted to 6.5 with citric acid. The experiment was laid out in a randomized complete block design with five experimental units (plants) of each treatment in each of two blocks (total of 70 plants).

Fruit harvest started on 1 May and continued to 1 June, at which time the experiment was ended (total of three mature trusses plus all remaining immature fruit). Fruit from each plant were weighed at harvest and graded individually to maxi-extra large, extra large, large, medium, and small $(>8.9>7.0>$ $6.4>5.7>5.1 \mathrm{~cm}$ in diameter, respectively). Unmarketable fruit equal to or less than 5.1 $\mathrm{cm}$ in diameter or with obvious blemishes, cuticle cracking, splitting, blossom-end rot, or irregular shape were treated as culls.

Expt. 2. Seeds of the cluster cultivar Idool (Seminis Seeds, Saint Louis, MO) were sown on 29 Apr. and transplanted to the experimental greenhouse compartment on 10 June. Three substrates were used, all with a base of peat/perlite: 1) peat/perlite (control); 2) 50\% YW compost (described in Expt. 1); and 3) $50 \%$ mushroom (Mush) compost. All mixes were blended on a volume/volume basis. Mushroom compost was obtained from All Seasons Mushrooms (Abbotsford, BC, Canada). The raw material was composed of $58 \%$ wheat straw $(0.35 \% \mathrm{~N}$ on a dry weight basis and $12 \%$ moisture), $38 \%$ dry poultry waste $(3.6 \% \mathrm{~N}$ on a dry weight basis and $25 \%$ moisture), and $4 \%$ gypsum (10\% moisture). The mineral analysis of the spent mushroom compost is detailed in Table 1. In addition, three liquid feeds were tested: standard hydroponic feed (control), organic feed B originally used in Expt. 1 but now at two concentrations (the low concentration of application used the same ratio of Grow, Bloom, and Thrive Alive as that of Expt. 1 and the high concentration used a ratio of 4.55:4.50:0.50 of Grow, Bloom, and Thrive
Alive, respectively), and a fish-based organic feed (organic feed C), also at two concentrations (Table 2). The fish product was OMRI-certified Pacific Natural (2-3-0.3) from Great Pacific BioProducts Ltd. (Delta, BC, Canada). All liquid fertilizer treatments began on the day of transplanting. The treatments for Expt. 2 are summarized in Table 4. A randomized complete block design with two blocks was used with seven experimental units (plants) of each treatment per block (total of 126 plants).

Fruit harvest was from 7 Aug. to 22 Oct. at which time the experiment was ended (total of nine mature trusses plus all remaining immature fruit). Because a cluster variety was used, fruit were weighed by truss rather than individually. A cluster was harvested when half the fruit had reached breaker stage. Cluster weight and fruit number were recorded. Culls (unmarketable fruit with blossom end rot, severe cuticle cracking, or nonuniform shape) were then removed and their weight and number recorded. Finally, Grade 2 fruit (still marketable fruit with skin blemishes, scars, or small cracks) were then removed and weighed.

Postharvest analysis of fruit quality was conducted only in Expt. 2. Fruit were obtained from two harvests, on 19 Sept. and on 5 Oct. 2008. At each harvest, 10 fruit of each treatment were randomly selected for postharvest quality evaluation. Fruit were stored for 3 weeks in a cooler with an air temperature of $10^{\circ} \mathrm{C}$ (with fluctuation of $0.5^{\circ} \mathrm{C}$ ) and relative humidity of $\approx 80 \%$. Each fruit was visually evaluated individually on the day of harvest and three times a week thereafter. Scores of decay index were: $0=$ no sign of decay, still firm; 1 = first sign of decay on fruit surface or stem, still firm; 2 = decay on less than $10 \%$ of fruit surface with no lesions, still firm enough to market; 3 = first lesion or too soft to be considered marketable, end of shelf life; $4=$ multiple lesions or severe desiccation and soft; and $5=$ severe decay with fluid leakage and/or very soft with severe desiccation, not consumable. Only the decay index at the end of $21 \mathrm{~d}$ is reported here. The data of the two harvests were combined.

Fusarium crown and root rot, caused by Fusarium oxysporum f.sp. radicis-lycopersici, was found in some treatments in the second experiment. On two sample dates, 15 Sept. and 4 Nov., plants were scored as being diseased on the basis of visible symptoms of crown rot and wilting.

Physical analysis. Substrate sampling for bulk density and waterholding capacity was conducted in the second experiment on 25 Oct. 2008. Undisturbed substrate core samples were collected with an edge-sharpened cylinder $(4.8 \mathrm{~cm}$ internal diameter, $2 \mathrm{~cm}$ height; $36.2-\mathrm{cm}^{3}$ volume) $\approx 10 \mathrm{~cm}$ from the top of each pot. Media above and below the core was carefully removed with a knife. There were 14 samples per treatment. Samples were oven-dried for $2 \mathrm{~d}$ at $60{ }^{\circ} \mathrm{C}$ and bulk density of the substrate was calculated. The oven-dried cores were then rewetted with $50 \mathrm{~mL}$ water, allowed to absorb water for $1 \mathrm{~h}$, and the extra water was then removed. An additional $10 \mathrm{~mL}$ of water was

Table 3. Compost and liquid feed treatments in Expt. 1.

\begin{tabular}{|c|c|c|}
\hline Treatment abbreviation & Substrate & Liquid feed \\
\hline Control & $80 \%$ peatmoss, $20 \%$ perlite & Hydroponic \\
\hline 20YW-FeedA & $20 \%$ yard waste compost ${ }^{z}$ & Organic feed $\mathrm{A}^{\mathrm{x}}$ \\
\hline 20YW-FeedB & $20 \%$ yard waste compost ${ }^{2}$ & Organic feed B \\
\hline 20Sw20YW-FeedA & $20 \%$ swine compost, $20 \%$ yard waste compost ${ }^{\mathrm{y}}$ & Organic feed A \\
\hline 20Sw20YW-FeedB & $20 \%$ swine compost, $20 \%$ yard waste compost ${ }^{\mathrm{y}}$ & Organic feed B \\
\hline 40YW-FeedA & $40 \%$ yard waste compost $\mathrm{t}^{\mathrm{y}}$ & Organic feed A \\
\hline 40YW-FeedB & $40 \%$ yard waste compost ${ }^{\mathrm{y}}$ & Organic feed B \\
\hline
\end{tabular}

${ }^{\mathrm{z}}$ In $60 \%$ peatmoss and $20 \%$ perlite.

${ }^{\mathrm{y}} \mathrm{In} 40 \%$ peatmoss and $20 \%$ perlite.

${ }^{x}$ Feed consisted of $\mathrm{K}_{2} \mathrm{SO}_{4}$, calpril, dolopril.

${ }^{\text {w}}$ Feed consisted of $\mathrm{K}_{2} \mathrm{SO}_{4}$, calpril, dolopril, Technaflora products.

Table 4. Compost and liquid feed treatments in Expt. 2.

\begin{tabular}{|c|c|c|}
\hline Treatment abbreviation & Substrate & Liquid feed \\
\hline Control & $80 \%$ peatmoss, $20 \%$ perlite & Hydroponics \\
\hline 50YW-Feed C High & $50 \%$ yard waste compost ${ }^{2}$ & Organic feed C High \\
\hline 50YW-Feed B High & $50 \%$ yard waste compost ${ }^{\mathrm{z}}$ & Organic feed B High ${ }^{x}$ \\
\hline 50YW-Feed B Low & $50 \%$ yard waste compost ${ }^{2}$ & Organic feed B Low \\
\hline 50YW-Feed C Low & $50 \%$ yard waste compost ${ }^{\mathrm{z}}$ & Organic feed C Low ${ }^{v}$ \\
\hline 50Mush-Feed C High & $50 \%$ mushroom compost ${ }^{\mathrm{z}}$ & Organic feed C High \\
\hline 50Mush-Feed B High & $50 \%$ mushroom compost ${ }^{z}$ & Organic feed B High \\
\hline 50Mush-Feed B Low & $50 \%$ mushroom compost ${ }^{2}$ & Organic feed B Low \\
\hline 50Mush-Feed C Low & $50 \%$ mushroom compost ${ }^{2}$ & Organic feed C Low \\
\hline
\end{tabular}

${ }^{\mathrm{z} I n} 30 \%$ peatmoss and $20 \%$ perlite.

${ }^{y}$ Feed consisted of $\mathrm{K}_{2} \mathrm{SO}_{4}$, calpril, dolopril, and Pacific Natural products (fish-based organic) at high concentration.

${ }^{x}$ Feed consisted of $\mathrm{K}_{2} \mathrm{SO}_{4}$, calpril, dolopril, and Technaflora products at high concentration.

${ }^{w}$ Feed consisted of $\mathrm{K}_{2} \mathrm{SO}_{4}$, calpril, dolopril, and Pacific Natural products (fish-based organic) at low concentration.

vFeed consisted of $\mathrm{K}_{2} \mathrm{SO}_{4}$, calpril, dolopril, and Technaflora products at low concentration. 
added to the sample to ensure complete saturation; the excess was then removed with a syringe. The waterholding capacity for each sample was calculated as (weight of saturated sample - weight of dry sample)/ volume of the core.

Mineral analysis. For the first experiment, three recently expanded leaves from the top of each plant were collected on 26 Mar. with 10 plants per treatment. All leaflets per treatment were pooled together, dried, and ground to 20 mesh. On 20 Oct. 2008, three fully expanded leaves from the top of each plant were collected for the second experiment. After drying and grinding to 20 mesh, samples from each of two plants were randomly combined for a total of four samples per treatment.

Substrate sampling was conducted after the last tomato harvest in Expt. 2 on 28 Oct. 2008. Samples of $\approx 1 \mathrm{~kg}$ of substrate were taken from eight randomly selected pots in each treatment and combined in pairs for a total of four samples. Samples were ovendried for $3 \mathrm{~d}$ at $60^{\circ} \mathrm{C}$. The leaf and substrate samples were submitted to A \& L Canada Laboratories Inc. (Winnipeg, MB, Canada) for mineral analysis. Leaf minerals were determined by inductively coupled plasma spectroscopy after nitric and hydrochloric acid digestion and substrate minerals, electrical conductivity, carbon, $\mathrm{C} / \mathrm{N}$, and $\mathrm{pH}$ were determined by Test Methods for the Examination of Composting and Compost (TMECC, 2009) protocols.

Substrate biological analyses. Substrate biological analyses were conducted in both experiments. At each sample date, substrate from two randomly selected pots per treatment, with two cores $(2.5 \mathrm{~cm}$ diameter $\times 15$ $\mathrm{cm}$ deep) from each pot, were mixed together as one replicate. In the first experiment, samples were collected in the middle of the experiment on 21, 22, and 25 Apr. (total of three replicates, each taken on a different day) and just before ending the crop on 27 May (five replicates, all taken on the same day). In Expt. 2, samples were collected before transplanting (10 June), in the middle of the experiment (5 Aug.), and near the end of the crop (23 Sept.). Samples were stored at $4{ }^{\circ} \mathrm{C}$ until used.

Fluorescein diacetate analysis hydrolysis was used as a measure of total microbial activity because it is simple, rapid, and sensitive (Schnürer and Rosswall, 1982). FDA activity has also frequently been correlated with compost-related suppression of plant diseases (Hoitink and Boehm, 1999). The method was adapted from Green et al., 2006. The samples were first sieved to pass through a 5-mm mesh. One gram (fresh weight) of substrate was placed in a 125$\mathrm{mL}$ Erlenmeyer flask and $50 \mathrm{~mL}$ of $60 \mathrm{mM}$ sodium phosphate buffer ( $\mathrm{pH}$ 7.6) was added. Stock solution $(0.5 \mathrm{~mL}$ of $4.9 \mathrm{mM}$ FDA) was added to start the reaction. Blanks prepared either without the addition of the FDA solution or without sample were measured along with a suitable number of sample replicates. The flasks were then placed in an oven at $37^{\circ} \mathrm{C}$ for $3 \mathrm{~h}$. Once removed from the oven, $2 \mathrm{~mL}$ of acetone was added immediately to end the reaction. The flasks were shaken thoroughly by hand. The contents of the flasks were then transferred to $50-\mathrm{mL}$ centrifuge tubes and centrifuged at $1725 \mathrm{rpm}$ for $6 \mathrm{~min}$. The supernatant from each sample was then filtered (Whatman No.2 filter paper) into tubes and the filtrates measured at 490 $\mathrm{nm}$ on a spectrophotometer (Ultrospec 1100 Pro, ultraviolet/visible spectrophotometer; Biochrom, Cambridge, U.K.).

Substrate samples for nematode analyses were the same as those used for the FDA analyses. Nematodes were extracted from 60$\mathrm{mL}$ substrate subsamples using Baermann pans (16 cm diameter, 7-d incubation) (Forge and Kimpinski, 2007). The nematodes were heat-killed $\left(70{ }^{\circ} \mathrm{C}\right.$ for $\left.1 \mathrm{~min}\right)$ and preserved in $4 \%$ formalin. Subsequently, 5-mL aliquots of appropriate dilutions of the nematode suspensions were poured onto a gridded counting dish on an inverted microscope and total nematodes were counted at $40 \times$ magnification.

The community-level physiological profile (diversity) of the bacterial community was assessed on substrate samples (the same as those for FDA and nematodes) from the second experiment only. EcoLog plates (BioLog Inc., Hayward, CA) were seeded with $0.15 \mathrm{~mL}$ of $1: 1000$ and $1: 10,000$ dilutions (in phosphate buffer) of substrate subsamples. An automatic plate reader was used to assess color development at 1, 2, 3, 4, 5, and $7 \mathrm{~d}$ after inoculation of the plates. Color intensity was averaged over the three replicates for each substrate in each plate. The time integral of absorbance readings was approximated using a difference equation. The number of substrates used by Day 7 was used as an indicator of the diversity of catabolic capacities in the bacterial community. The time integral of average absorbance per positive substrate and the number of substrates used were the parameters that were analyzed statistically.

Statistical analysis. The data were analyzed using the General Linear Model (GLM) of SAS (SAS Institute, Cary, NC). Duncan's multiple range tests were used for means separation among treatments, and orthogonal contrasts were used to evaluate groupings of treatments. Relationships between biological factors were analyzed using the Regression (REG) procedure of SAS.

\section{Results}

Expt. 1. In the first experiment, treatments had significant effects on yield (Table 5). The conventional hydroponic treatment resulted in significantly higher yield (marketable and total) than any of the organic treatments. The organic treatment showing yield closest to the hydroponic control was $40 \mathrm{Van}-\mathrm{FeedB}$ at $82 \%$ of the control. Within the organic treatments, yields (marketable and total) in descending order were $40 \mathrm{Van}-\mathrm{FeedB}=20 \mathrm{Van}-$ FeedB $>$ 20Sw20Van-FeedB $=$ 20Sw20VanFeedA $>40$ Van-FeedA $=20$ Van-FeedA. The organic treatment showing the lowest yield was $18 \%$ of that of the hydroponic control. Organic feed B generally resulted in significantly higher yield (marketable, unmarketable, and total) than did Feed A, which had no $\mathrm{N}$ or $\mathrm{P}$.

The mineral content of leaf tissue could not be statistically evaluated because all

Table 5. Treatment effects on yield, microbivorous nematodes, and FDA analysis in Expt. 1.

\begin{tabular}{|c|c|c|c|c|c|c|c|}
\hline \multirow[b]{2}{*}{ Treatment } & \multicolumn{3}{|c|}{ Yield (kg/plant) } & \multicolumn{2}{|c|}{ Nematodes (per $60 \mathrm{~mL}$ ) } & \multicolumn{2}{|c|}{ FDA (mg $\cdot \mathrm{kg}^{-1}$ soil $\left./ 3 \mathrm{~h}\right)$} \\
\hline & Marketable & Unmarketable & $\overline{\text { Total }}$ & 21 Apr. & 27 May & 21 Apr. & 27 May \\
\hline Control & $5.59 \mathrm{a}^{\mathrm{z}}$ & $0.21 \mathrm{~b}$ & $5.80 \mathrm{a}$ & $1,364 \mathrm{~d}^{\mathrm{y}}$ & $2,086 \mathrm{c}$ & 2.16 & $2.38 \mathrm{~cd}$ \\
\hline 20YW-FeedA & $0.97 \mathrm{~d}$ & $0.07 \mathrm{c}$ & $1.03 \mathrm{~d}$ & $2,992 \mathrm{c}$ & $2,922 \mathrm{bc}$ & 2.24 & $2.15 \mathrm{~d}$ \\
\hline 20YW-FeedB & $4.14 \mathrm{~b}$ & $0.26 \mathrm{~b}$ & $4.40 \mathrm{~b}$ & $5,104 \mathrm{bc}$ & $4,189 \mathrm{abc}$ & 2.53 & $3.37 \mathrm{~b}$ \\
\hline 20Sw20YW-FeedA & $2.31 \mathrm{c}$ & $0.23 \mathrm{~b}$ & $2.54 \mathrm{c}$ & $8,653 \mathrm{ab}$ & $4,391 \mathrm{ab}$ & 2.98 & $2.45 \mathrm{~cd}$ \\
\hline 20Sw20YW-FeedB & $2.46 \mathrm{c}$ & $0.53 \mathrm{a}$ & $2.99 \mathrm{c}$ & $12,540 \mathrm{a}$ & $6,987 \mathrm{ab}$ & 2.99 & $3.76 \mathrm{ab}$ \\
\hline 40YW-FeedA & $1.44 \mathrm{~d}$ & $0.05 \mathrm{c}$ & $1.49 \mathrm{~d}$ & $4,723 \mathrm{c}$ & $6,670 \mathrm{a}$ & 2.47 & $3.11 \mathrm{bc}$ \\
\hline 40YW-FeedB & $4.49 \mathrm{~b}$ & $0.25 \mathrm{~b}$ & $4.74 \mathrm{~b}$ & $6,336 \mathrm{bc}$ & $5,949 \mathrm{ab}$ & 2.73 & $4.18 \mathrm{a}$ \\
\hline \multicolumn{8}{|c|}{ Significance of selected a priori contrasts of treatment effects: } \\
\hline Control versus organic & $* * *$ & NS & $* * *$ & $* * *$ & $* *$ & NS & $* *$ \\
\hline Feed A versus Feed B & $* * *$ & $* * *$ & $* * *$ & NS & NS & NS & $* * *$ \\
\hline $20 Y W$ versus $20 \mathrm{YW} 20 \mathrm{Sw}$ & NS & $* * *$ & NS & $* * *$ & NS & NS & NS \\
\hline $20 \mathrm{YW}$ versus $40 \mathrm{YW}$ & NS & NS & NS & NS & $*$ & NS & $* *$ \\
\hline $20 Y W 20 \mathrm{Sw}$ versus $40 \mathrm{YW}$ & $* *$ & $* * *$ & NS & $* * *$ & NS & NS & $*$ \\
\hline
\end{tabular}

${ }^{\mathrm{z} N e m a t o d e}$ counts are presented, but data were $\log 10$ transformed for statistical analysis.

${ }^{y}$ Means within each column that are followed by different letters are significantly different $(P<0.05)$ according to Duncan's multiple range test.

NS, *,**,***Nonsignificant or significant at $P \leq 0.05, P \leq 0.01$, or $P \leq 0.001$, respectively.

$\mathrm{FDA}=$ fluorescein diacetate analysis 
samples for each treatment were pooled before analysis, but some broad generalizations could be observed. Nitrogen was similar in the hydroponic control treatment and in those with swine compost (5.94\% and 5.52\% \pm 0.01 , respectively; mean \pm SD) but lower in all other treatments $(2.42 \% \pm 0.40)$. Potassium was highest in treatments with swine compost $(5.05 \% \pm 0.05)$ and somewhat lower in all other treatments $(3.37 \% \pm$ $0.54)$. Iron was higher in the control treatment $(164 \mathrm{ppm})$ than in the organic treatments $(96 \mathrm{ppm} \pm 18)$. Other elements were similar in all treatments.

The effect of treatments on nematode populations in Expt. 1 is shown in Table 5. Only bacterial-feeding and fungal-feeding nematodes were observed in the samples. In the first sample (21 Apr.), 20Sw20YWFeedB had significantly more nematodes than any other treatment except 20Sw20 YW-FeedA. None of the other organic treatments differed from each other. Substrate with 20Sw20YW had higher nematode populations than did substrate with $20 \mathrm{YW}$ or $40 \mathrm{YW}$. In the second sampling (27 May), the $40 \mathrm{YW}$-Feed A treatment had significantly more nematodes than 20YW-Feed A and the hydroponic control. None of the other organic treatments differed from each other. Contrast analysis showed that, collectively, the $40 \mathrm{YW}$ treatments had higher nematode populations than did the $20 \mathrm{YW}$ treatments. On both sampling dates, organic treatments had significantly higher nematode counts than the hydroponic control, but organic feed A and organic feed B treatments did not differ.

There were no significant differences in FDA measurements among the seven treatments in the first sampling of Expt. 1 (Table 5). However, in the second sampling, feed B organic treatments were significantly higher than the control, and the $40 \mathrm{YW}$-Feed B treatment was significantly higher than most other treatments. From the contrast analyses, the hydroponic control showed lower FDA values than the organic treatments, and organic feed A was less than organic feed B. In addition, the 40YW treatments showed significantly higher FDA values than the $20 \mathrm{YW}$ treatments, and the $40 \mathrm{YW}$ treatments were greater than the $20 \mathrm{YW} 20 \mathrm{Sw}$ treatments.

Expt. 2. In the second experiment, treatments had significant effects on yield (Table 6). Organic treatments 50Mush-Feed B Low and 50YW-Feed B Low resulted in comparable yield (marketable and total) to the hydroponic control. Within the organic treatments, yields (total) in descending order were 50Mush-Feed B Low $=50 \mathrm{YW}$-Feed B Low $>50$ Mush-Feed C Low $=50$ YW-Feed C Low $>50 \mathrm{YW}$-Feed B High $=50 \mathrm{Mush}-\mathrm{Feed}$ $\mathrm{B}$ High $=50 \mathrm{YW}$-Feed $\mathrm{C}$ High $=50$ MushFeed C High. Note that 50YW-Feed B High was greater than $50 \mathrm{YW}$-Feed $\mathrm{C}$ High and 50Mush-Feed C High and that 50Mush-Feed B High was greater than 50Mush-Feed C High. From the contrast analyses, the control treatment was generally significantly higher than the organic treatments. Low concentrations of organic feed resulted in significantly higher yield (marketable, unmarketable, and total) compared with higher concentrations of organic feed. Organic feed B generally resulted in significantly higher yield (marketable and total) than did Feed C. There was no significant difference in yield (marketable and total) resulting from the different composts. However, YW compost produced more unmarketable fruit than did the mushroom compost.

The analysis of postharvest data are shown in Table 6. Overall, the hydroponic control was inferior in postharvest quality to the eight organic treatments, having a high decay index of $4.7(P=0.003)$. In order of decreasing postharvest quality, treatments could be arranged as 50YW-Feed B High, 50Mush-Feed C High, 50Mush-Feed B High, 50YW-Feed C High, 50YW-Feed B Low, 50YW-Feed C Low, 50Mush-Feed C Low, 50Mush-FeedB Low, and control. Generally, contrast analysis showed no difference between the two types of liquid organic fertilizer. Yard waste compost was superior (low decay index) to mushroom compost and the high concentration of liquid organic fertilizer was superior (low decay index) to the low concentration. There was a positive relationship between yield and postharvest decay $\left(\mathrm{y}=-7.8+3.3 \mathrm{x}, \mathrm{R}^{2}=0.72, \mathrm{P}=0.004\right.$; data taken from treatment means).

Substrates in Expt. 2 sampled before transplanting showed significant differences in nematode counts (Table 7). As for Expt. 1, only bacterial-feeding and fungal-feeding nematodes were observed. The lowest counts were found in the hydroponic control and the highest in the mushroom compost. The effect of treatments on nematode populations in Expt. 2 is shown in Table 8. In the sample taken on 5 Aug., 50YW-Feed C High had significantly more nematodes than 50YWFeed C Low and more nematodes than any other treatment, including the control. Except for these two treatments, most of the organic treatments did not differ from each other. From contrast analyses, organic feed treatments had significantly higher nematode counts than the control. Organic feed C treatments showed higher nematode counts than did the organic feed B treatments. There was no significant difference in nematode counts between high and low organic feed concentrations. Yard waste compost showed a significantly higher nematode count than did the mushroom compost.

In the nematode sample taken on 23 Sept., 50YW-Feed C High and Low and 50MushFeed $\mathrm{C}$ High and Low treatments had significantly more nematodes than any other treatment, including the control. Results of contrasts were the same as found for the 5 Aug. samples.

In terms of pretreatment FDA values for Expt. 2, there were no differences between the control and the YW compost, but the mush compost had higher values (Table 7). After treatments were applied, there were significant differences in FDA measurements among the nine treatments in the August sampling of Expt. 2 (Table 8). The 50YWFeedC Low, 50YW-FeedC High, 50MushFeedB High, and 50Mush-Feed C High treatments showed significantly higher FDA activity than the control. None of the other organic treatments differed from the control

Table 6. Treatment effects on yield and postharvest decay in Expt. 2.

\begin{tabular}{|c|c|c|c|c|}
\hline \multirow[b]{2}{*}{ Treatment } & \multicolumn{3}{|c|}{ Yield (kg/plant) } & \multirow[b]{2}{*}{ Decay index after 21} \\
\hline & Marketable & Unmarketable & Total & \\
\hline Control & $8.21 \mathrm{a}^{\mathrm{z}}$ & $0.28 \mathrm{def}$ & $8.49 \mathrm{a}$ & $4.7 \mathrm{ab}$ \\
\hline 50YW-Feed C High & $2.68 \mathrm{~cd}$ & $0.67 \mathrm{~b}$ & $3.35 \mathrm{de}$ & $3.6 \mathrm{cde}$ \\
\hline 50YW-Feed B High & $3.24 \mathrm{c}$ & $1.09 \mathrm{a}$ & $4.34 \mathrm{c}$ & $3.0 \mathrm{e}$ \\
\hline 50YW-Feed B Low & $7.82 \mathrm{a}$ & $0.46 \mathrm{bcd}$ & $8.28 \mathrm{a}$ & $3.9 \mathrm{~cd}$ \\
\hline 50YW-Feed C Low & $6.18 \mathrm{~b}$ & $0.59 \mathrm{bc}$ & $6.77 \mathrm{~b}$ & $4.1 \mathrm{bc}$ \\
\hline 50Mush-Feed C High & $2.25 \mathrm{~d}$ & 0.40 cde & $2.65 \mathrm{e}$ & $3.4 \mathrm{de}$ \\
\hline 50Mush-Feed B High & $3.37 \mathrm{c}$ & $0.20 \mathrm{ef}$ & $3.57 \mathrm{~cd}$ & 3.6 cde \\
\hline 50Mush-Feed B Low & $8.42 \mathrm{a}$ & $0.10 \mathrm{f}$ & $8.52 \mathrm{a}$ & $4.8 \mathrm{a}$ \\
\hline 50Mush-Feed C Low & $6.64 \mathrm{~b}$ & $0.35 \mathrm{cdef}$ & $6.99 \mathrm{~b}$ & $4.7 \mathrm{ab}$ \\
\hline \multicolumn{5}{|c|}{ Significance of selected contrasts of treatment effects: } \\
\hline Control versus organic & $* * *$ & $*$ & $* * *$ & * \\
\hline High versus low & $* * *$ & $* * *$ & $* * *$ & * \\
\hline Feed $\mathrm{B}$ versus $\mathrm{C}$ & $* * *$ & NS & $* * *$ & NS \\
\hline YW versus mush & NS & $* * *$ & NS & * \\
\hline
\end{tabular}

${ }^{\mathrm{z}}$ Means within each column that are followed by different letters are significantly different $(P<0.05)$ according to Duncan's multiple range test.

Ns, *,**,**Nonsignificant or significant at $P \leq 0.05, P \leq 0.01$, or $P \leq 0.001$, respectively.

Table 7. Initial microbivorous nematode counts and FDA values in each substrate in Expt. 2.

\begin{tabular}{|c|c|c|}
\hline Substrate & Nematodes (per $60 \mathrm{~mL}$ substrate) & FDA (mg. $\mathrm{kg}^{-1}$ soil $\left./ 3 \mathrm{~h}\right)$ \\
\hline Control & $2,710 c^{z, y}$ & $2.51 \mathrm{~b}$ \\
\hline $50 Y W$ & $4,576 \mathrm{~b}$ & $2.95 \mathrm{~b}$ \\
\hline 50Mush & $9,900 \mathrm{a}$ & $8.08 \mathrm{a}$ \\
\hline
\end{tabular}

${ }^{\mathrm{z}}$ Means within each column that are followed by different letters are significantly different $(P<0.05)$ according to Duncan's multiple range test.

${ }^{y}$ Nematode counts are presented, but data were $\log 10$ transformed for statistical analysis.

$\mathrm{FDA}=$ fluorescein diacetate analysis. 
Table 8. Treatment effects on substrate physical and microbiological characteristics in Expt. 2.

\begin{tabular}{|c|c|c|c|c|c|c|c|c|}
\hline \multirow[b]{2}{*}{ Treatment } & \multirow{2}{*}{$\begin{array}{c}\text { Bulk } \\
\text { density } \\
\left(\mathrm{g} \cdot \mathrm{cm}^{-3}\right)\end{array}$} & \multirow{2}{*}{$\begin{array}{c}\text { Waterholding } \\
\text { capacity } \\
\left(\mathrm{g} \cdot \mathrm{cm}^{-3}\right)\end{array}$} & \multicolumn{2}{|c|}{$\begin{array}{l}\text { Microbivorous nematodes } \\
\text { (per } 60 \mathrm{~mL} \text { ) }\end{array}$} & \multicolumn{2}{|c|}{ FDA (mg $\cdot \mathrm{kg}^{-1}$ soil $\left./ 3 \mathrm{~h}\right)$} & \multirow{2}{*}{$\begin{array}{c}\text { EcoLog } \\
\text { substrates } \\
\text { used }\end{array}$} & \multirow{2}{*}{$\begin{array}{l}\text { Fusarium } \\
\qquad(\%)\end{array}$} \\
\hline & & & 5 Aug. & 23 Sept. & 5 Aug. & 23 Sept. & & \\
\hline Control & $0.119 \mathrm{c}^{\mathrm{z}}$ & $0.730 \mathrm{a}$ & $678 \mathrm{e}^{\mathrm{y}}$ & $590 \mathrm{~d}$ & $2.08 \mathrm{~d}$ & $1.64 \mathrm{~d}$ & $26.6 \mathrm{ab}$ & 0 \\
\hline 50YW-Feed C High & $0.227 \mathrm{a}$ & $0.596 \mathrm{bc}$ & $42,742 \mathrm{a}$ & $24,728 \mathrm{a}$ & $3.46 \mathrm{ab}$ & $3.11 \mathrm{ab}$ & $27.2 \mathrm{ab}$ & 36 \\
\hline 50YW-Feed B High & $0.223 \mathrm{a}$ & $0.610 \mathrm{~b}$ & $1,910 \mathrm{~cd}$ & $1,883 \mathrm{c}$ & $2.38 \mathrm{~cd}$ & $1.97 \mathrm{~d}$ & $17.6 \mathrm{~d}$ & 14 \\
\hline 50YW-Feed B Low & $0.213 \mathrm{a}$ & $0.610 \mathrm{~b}$ & $1,426 \mathrm{~d}$ & $3,247 \mathrm{c}$ & $2.51 \mathrm{bcd}$ & $1.81 \mathrm{~d}$ & $25.6 \mathrm{bc}$ & 7 \\
\hline 50YW-Feed C Low & $0.226 \mathrm{a}$ & $0.589 \mathrm{bcd}$ & $10,930 \mathrm{~b}$ & $21,560 \mathrm{ab}$ & $3.80 \mathrm{a}$ & $2.31 \mathrm{~cd}$ & $28.2 \mathrm{ab}$ & 0 \\
\hline 50Mush-Feed C High & $0.162 \mathrm{~b}$ & $0.557 \mathrm{~d}$ & $1,751 \mathrm{~cd}$ & $11,792 \mathrm{~b}$ & $3.21 \mathrm{abc}$ & $3.82 \mathrm{a}$ & $23.0 \mathrm{c}$ & 25 \\
\hline 50Mush-Feed B High & $0.149 \mathrm{~b}$ & $0.620 \mathrm{~b}$ & $1,021 \mathrm{de}$ & $1,390 \mathrm{c}$ & $3.30 \mathrm{abc}$ & $2.29 \mathrm{~cd}$ & $25.0 \mathrm{bc}$ & 4 \\
\hline 50Mush-Feed B Low & $0.149 \mathrm{~b}$ & $0.564 \mathrm{~cd}$ & $1,566 \mathrm{~cd}$ & $1,408 \mathrm{c}$ & $2.79 \mathrm{abcd}$ & $1.86 \mathrm{~d}$ & $29.4 \mathrm{a}$ & 0 \\
\hline 50Mush-Feed C Low & $0.155 \mathrm{~b}$ & $0.593 \mathrm{bcd}$ & $2,684 \mathrm{c}$ & $19,228 \mathrm{ab}$ & 3.10 abcd & $2.91 \mathrm{bc}$ & $25.2 \mathrm{bc}$ & 0 \\
\hline \multicolumn{9}{|c|}{ Significance of selected a priori contrasts of treatment effects: } \\
\hline Control versus organic & $* * *$ & $* * *$ & $* * *$ & $* * *$ & ** & ** & NS & \\
\hline High versus low & NS & NS & NS & NS & NS & ** & $* * *$ & \\
\hline Feed $\mathrm{B}$ versus $\mathrm{C}$ & * & NS & $* * *$ & $* * *$ & $* *$ & $* * *$ & NS & \\
\hline YW versus mush & $* * *$ & $*$ & $* * *$ & $* *$ & NS & $*$ & NS & \\
\hline
\end{tabular}

${ }^{z}$ Means within each column that are followed by different letters are significantly different $(P<0.05)$ according to Duncan's multiple range test.

yematode counts are presented, but data were $\log 10$ transformed for statistical analysis.

Ns, *,**, ***Nonsignificant or significant at $P \leq 0.05, P \leq 0.01$, or $P \leq 0.001$, respectively.

$\mathrm{FDA}=$ fluorescein diacetate analysis.

Table 9. Selected significant relationships among microbial and yield measurements in Expts. 1 and 2.

\begin{tabular}{lllll}
\hline Relationship $^{\mathrm{z}}$ & \multicolumn{1}{c}{ Analysis $^{\mathrm{y}}$} & Equation & $R^{2}$ & $P$ \\
\hline FDA and nematodes $^{\mathrm{x}}$ & Expt. 2, sample 1 & $\mathrm{y}=-1.47+1.32 \mathrm{x}$ & 0.30 & 0.01 \\
& Expt. 2, sample 2 & $\mathrm{y}=-0.75+0.79 \mathrm{x}$ & 0.38 & 0.004 \\
Yield and FDA & Expt. 1, sample 2 & $\mathrm{y}=-0.46+1.95 \mathrm{x}$ & 0.36 & 0.0005 \\
& Expt. 2, sample 2 & $\mathrm{y}=16.34-1.5 \mathrm{x}$ & 0.42 & 0.002 \\
Yield and nematodes $^{\mathrm{x}}$ & Expt. 2, sample 1 & $\mathrm{y}=28.62-3.89 \mathrm{x}$ & 0.44 & 0.001 \\
& Expt. 2, sample 2 & $\mathrm{y}=22.54-2.54 \mathrm{x}$ & 0.73 & $<0.0001$ \\
\hline
\end{tabular}

${ }^{2}$ Dependent variable is followed by independent variable.

y Unless otherwise indicated, the analysis does not include hydroponic control data. In Expt. 2, it also does not include data from high organic feed treatments because of fusarium crown and root rot contamination. Data were taken from individual samples (five replicates per treatment as described in the "Materials and Methods") as opposed to treatment means.

${ }^{x}$ Nematode count data were $\log$ transformed before regression analysis.

$\mathrm{FDA}=$ fluorescein diacetate analysis.

or from each other. Contrast analysis showed that organic feeds had higher overall FDA values than did the hydroponic control. In comparing feed types, organic feed $\mathrm{C}$ had significantly higher FDA values than did organic feed B.

There were also significant differences in FDA measurements in the September sampling (Table 8). The 50Mush-Feed C High, 50YW-Feed C High, and 50Mush-Feed C Low treatments showed significantly higher FDA values than the control. None of the other organic treatments differed from the control or from each other. Overall, contrast analysis showed that organic feeds had higher FDA values than did the hydroponic control. In comparing feed types, organic feed $\mathrm{C}$ had significantly higher FDA values than did organic feed $\mathrm{B}$. The higher concentrations of organic feeds had higher FDA values than did low concentrations. Mushroom compost showed significantly higher FDA values than did the yard waste compost.

Analyses of the community-level physiological profile of the bacterial community through EcoLog plates in the September sampling also revealed significant effects of treatments (Table 8). The total number of substrates used by the seventh day of incubation was greatest for the 50Mush-Feed B Low treatment, but it did not differ significantly from the control, which was interme- diate to the various organic treatment combinations. Bacterial communities in the 50Mush-Feed $\mathrm{C}$ High treatment and the 50YW-Feed B High treatments used significantly fewer substrates than the control. No other treatments were significantly different from the control. The contrast comparing high and low feed concentrations was highly significant with mean values of 23.2 and 27.1 for the high and low feeds, respectively.

The high concentration of organic feed $\mathrm{C}$ induced a high incidence of fusarium crown and root rot. On 15 Sept., other than one plant in the low concentration of organic feed B, plants receiving high organic feed $\mathrm{C}$ concentrations were the only ones to show symptoms of fusarium infection with $39 \%$ of the plants showing symptoms. By 4 Nov. (Table 8 ), $61 \%$ of all plants receiving the high concentration of organic feed C (both compost treatments combined) had symptoms of fusarium crown rot, and $18 \%$ of all plants receiving the high concentration of organic feed B had symptoms of fusarium crown rot. In all, 24 plants out of 126 (19\%) developed symptoms of fusarium crown and root rot.

The bulk density and waterholding capacity of the substrates in Expt. 2 are shown in Table 8 . Substrate bulk density was significantly higher in the organic treatments than in the hydroponic control, which was the lowest at $0.119 \mathrm{~g} \cdot \mathrm{cm}^{-3}$. From contrast analyses, yard waste compost had significantly higher bulk density than did mushroom compost. Organic feed $\mathrm{C}$ resulted in higher bulk density than that of organic feed $\mathrm{B}$. The waterholding capacity of the hydroponic control was $0.730 \mathrm{~g} \cdot \mathrm{cm}^{-3}$, which was significantly higher than the organic treatments. Yard waste compost had a higher waterholding capacity than did the mushroom compost. However, bulk density and waterholding capacity did not differ between high and low concentrations of the organic feeds.

For both experiments, substrate biological variables were regressed against each other and against yield. The hydroponic control was excluded from the analysis in both experiments as were the high organic feed treatments in the second experiment as a result of the occurrence of fusarium crown and root rot, which could confound any relationships with yield. A summary of significant regressions is presented in Table 9. In the first experiment (second sample date), FDA values were positively related to yield, but in the second experiment, FDA values were negatively related to yield as were nematode populations. Nematode populations were significantly correlated with FDA activity in Expt. 2.

Substrate mineral content measured at the end of the experiment is presented in Table 10. To summarize, contrast analysis showed that the eight organic treatments were significantly different from the hydroponic treatment in having higher $\mathrm{N}$, sulfur (S), $\mathrm{P}, \mathrm{K}, \mathrm{Ca}$, boron $(\mathrm{B})$, zinc $(\mathrm{Zn})$, manganese $(\mathrm{Mn})$, iron $(\mathrm{Fe})$, and copper $(\mathrm{Cu})$. Substrate electrical conductivity (EC) and saturated $\mathrm{pH}$ values were also higher in the organic treatments than in the hydroponic control. This was corroborated by measurements of leachate $\mathrm{EC}$ and $\mathrm{pH}$ collected on four occasions during the experiment (data not presented; leachate $\mathrm{pH}$ values were generally higher than the saturated $\mathrm{pH}$ values in all treatments). The high feed concentrations tended to have the greatest substrate $\mathrm{EC}$ values; the exception was 50Mush-Feed C High, which had an EC 


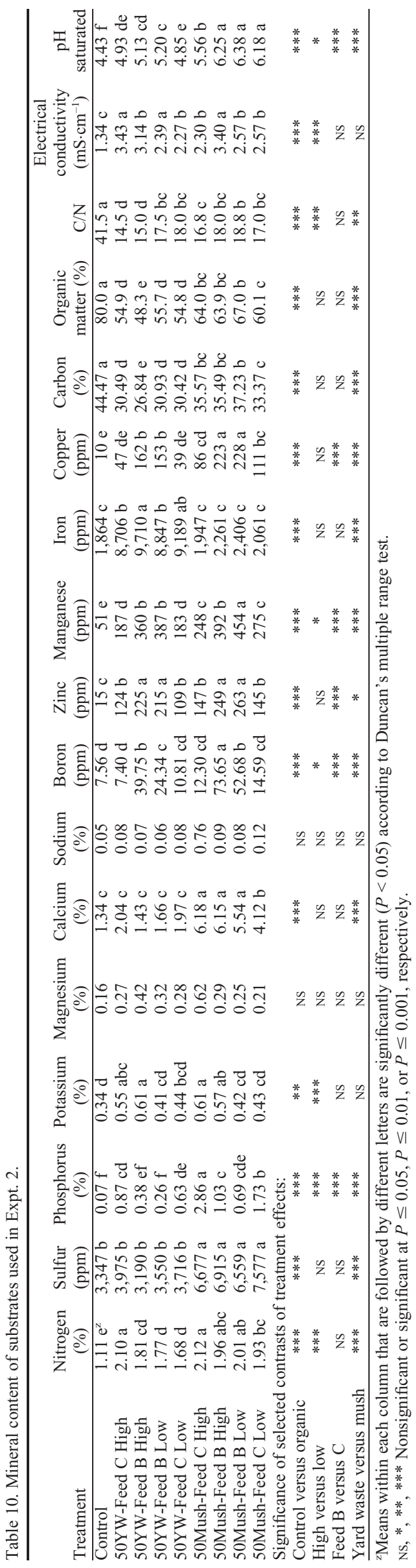

value similar to the low-feed concentrations.Percent organic matter and substrate $\mathrm{C} / \mathrm{N}$ ratio were lower in the organic treatments than in the hydroponic control. The low feed concentration had significantly lower $\mathrm{N}, \mathrm{P}, \mathrm{K}$, and $\mathrm{B}$ and higher $\mathrm{Mn}$ than the high-feed treatments; the $\mathrm{C} / \mathrm{N}$ ratio and $\mathrm{pH}$ were higher but the $\mathrm{EC}$ was lower. Feed $\mathrm{B}$ showed lower $\mathrm{P}$ but higher $\mathrm{B}, \mathrm{Zn}, \mathrm{Mn}$, and $\mathrm{Cu}$ than did feed $\mathrm{C}$, and its $\mathrm{pH}$ was also higher. In terms of the two composts, YW compost had lower N, S, P, Ca, B, Zn, Mn, and $\mathrm{Cu}$ and higher Fe. Percent carbon, organic matter, $\mathrm{C} / \mathrm{N}$, and $\mathrm{pH}$ were also lower in the YW compost.

In terms of foliar mineral content, contrast analysis showed that the only elements that were significantly different between the control and the organic treatments were $\mathrm{S}, \mathrm{P}, \mathrm{Ca}$, $\mathrm{B}, \mathrm{Mn}$, and $\mathrm{Cu}$ (Table 11). The leaf tissue content of $\mathrm{S}, \mathrm{P}, \mathrm{Mg}, \mathrm{Ca}, \mathrm{B}, \mathrm{Mn}$, and $\mathrm{Cu}$ were significantly higher in the leaves from the feed B treatments than in those from feed C; only the $\mathrm{Fe}$ content was significantly higher in the leaves from the feed $\mathrm{C}$ treatments. The high concentration of organic feed resulted in higher $\mathrm{S}, \mathrm{P}, \mathrm{Mg}, \mathrm{B}, \mathrm{Mn}$, and $\mathrm{Fe}$ and less $\mathrm{Ca}$ in leaves than did the low concentration. Mushroom compost resulted in significantly higher foliar $\mathrm{Ca}$ and $\mathrm{Cu}$ but less $\mathrm{B}, \mathrm{Mn}$, and $\mathrm{Fe}$ than did the YW compost.

\section{Discussion}

Studies comparing yield of organically and conventionally grown crops often give inconsistent results. Some studies have found yield to be lower in organic than in conventional treatments in both field and greenhouse crops (Heeb et al., 2005, 2006; Mäder et al., 2002). On the other hand, no significant differences in total marketable yield of sweet pepper (del Amor, 2007) and tomato (Rippy et al., 2004) have been observed when comparing organic and mineral fertilization, although in the study with tomato, the harvest duration was relatively short. Herencia et al. (2007) also found that crop yield was not statistically different between organic and mineral fertilizer treatments. In our first experiment, the hydroponic control had a higher yield than any of the organic treatments. The highest-yielding organic treatment $(40 \mathrm{YW}-\mathrm{FeedB})$ in the first experiment had a total yield that was $82 \%$ of the hydroponic control. However, in the second experiment, the combination of $50 \%$ compost with a low concentration of organic feed resulted in yield ranging from $80 \%$ to $100 \%$ that of the hydroponic control. The relatively higher organic yield in the second experiment may have been associated with the higher concentrations of composts used as well as the fact that liquid feed treatments started at transplanting rather than 1 month later, like in Expt. 1. In the second experiment, organic feed B produced significantly higher yield than did organic feed $\mathrm{C}$. The reason for this is unknown; the two feeds originated from different sources (plant versus fish) and although mineral composition of the two was as similar as we could manage, there were inevitably some differences both 
Table 11. Mineral content of recently fully expanded leaves from plants in Expt. 2.

\begin{tabular}{|c|c|c|c|c|c|c|c|c|c|c|c|c|}
\hline Treatment & $\begin{array}{c}\text { Nitrogen } \\
(\%)\end{array}$ & $\begin{array}{l}\text { Sulfur } \\
(\%)\end{array}$ & $\begin{array}{c}\text { Phosphorus } \\
(\%)\end{array}$ & $\begin{array}{c}\text { Potassium } \\
(\%)\end{array}$ & $\begin{array}{c}\text { Magnesium } \\
(\%)\end{array}$ & $\begin{array}{c}\text { Calcium } \\
(\%)\end{array}$ & $\begin{array}{l}\text { Sodium } \\
(\%)\end{array}$ & $\begin{array}{l}\text { Boron } \\
\text { (ppm) }\end{array}$ & $\begin{array}{c}\text { Zinc } \\
(\mathrm{ppm})\end{array}$ & $\begin{array}{c}\text { Manganese } \\
(\mathrm{ppm})\end{array}$ & $\begin{array}{l}\text { Iron } \\
(\mathrm{ppm})\end{array}$ & $\begin{array}{l}\text { Copper } \\
\text { (ppm) }\end{array}$ \\
\hline Control & 5.22 & $1.12 \mathrm{c}^{\mathrm{z}}$ & $0.61 \mathrm{bc}$ & 5.53 & $0.33 \mathrm{c}$ & $2.77 \mathrm{a}$ & 0.06 & $42.50 \mathrm{de}$ & 35.25 & $135.00 \mathrm{~d}$ & 78.75 bcde & $6.25 \mathrm{f}$ \\
\hline 50YW-Feed C High & 5.85 & $1.28 \mathrm{bc}$ & $0.85 \mathrm{a}$ & 5.16 & $0.24 \mathrm{~d}$ & $1.55 \mathrm{de}$ & 0.16 & $41.00 \mathrm{de}$ & 43.30 & $165.75 \mathrm{~d}$ & $120.00 \mathrm{a}$ & $7.00 \mathrm{f}$ \\
\hline 50YW-Feed B High & 5.61 & $1.71 \mathrm{a}$ & $0.71 \mathrm{~b}$ & 5.43 & $0.46 \mathrm{a}$ & $1.50 \mathrm{e}$ & 0.13 & $166.00 \mathrm{a}$ & 52.00 & $328.00 \mathrm{a}$ & $95.25 \mathrm{~b}$ & $9.25 \mathrm{def}$ \\
\hline 50YW-Feed B Low & 5.53 & $1.27 \mathrm{bc}$ & $0.66 \mathrm{bc}$ & 5.58 & $0.32 \mathrm{c}$ & $2.23 \mathrm{bc}$ & 0.07 & $63.00 \mathrm{c}$ & 51.75 & $279.75 \mathrm{~b}$ & $76.25 \mathrm{cde}$ & $11.50 \mathrm{de}$ \\
\hline 50YW-Feed C Low & 5.61 & $1.31 \mathrm{~b}$ & $0.66 \mathrm{bc}$ & 5.33 & $0.21 \mathrm{~d}$ & $1.97 \mathrm{~cd}$ & 0.15 & $33.00 \mathrm{e}$ & 36.25 & $210.25 \mathrm{c}$ & $88.00 \mathrm{bcd}$ & 7.50 ef \\
\hline 50Mush-Feed C High & 5.66 & $1.24 \mathrm{bc}$ & $0.83 \mathrm{a}$ & 4.99 & $0.19 \mathrm{~d}$ & $1.38 \mathrm{e}$ & 0.17 & $37.50 \mathrm{e}$ & 54.50 & $157.25 \mathrm{~d}$ & $93.25 \mathrm{bc}$ & $12.75 \mathrm{~cd}$ \\
\hline 50Mush-Feed B High & 5.61 & $1.63 \mathrm{a}$ & $0.64 \mathrm{bc}$ & 5.38 & $0.40 \mathrm{~b}$ & $2.76 \mathrm{a}$ & 0.10 & $113.75 \mathrm{~b}$ & 69.50 & $330.50 \mathrm{a}$ & 79.75 bcde & $20.25 \mathrm{a}$ \\
\hline 50Mush-Feed B Low & 5.43 & $1.30 \mathrm{bc}$ & $0.60 \mathrm{c}$ & 5.31 & $0.31 \mathrm{c}$ & $2.71 \mathrm{a}$ & 0.18 & $56.75 \mathrm{~cd}$ & 54.75 & $173.00 \mathrm{~cd}$ & $67.75 \mathrm{e}$ & $18.50 \mathrm{ab}$ \\
\hline 50Mush-Feed C Low & 5.40 & $1.40 \mathrm{~b}$ & $0.67 \mathrm{bc}$ & 5.45 & $0.24 \mathrm{~d}$ & $2.63 \mathrm{ab}$ & 0.14 & $30.50 \mathrm{e}$ & 60.50 & $150.75 \mathrm{~d}$ & $73.75 \mathrm{de}$ & $16.00 \mathrm{bc}$ \\
\hline \multicolumn{13}{|c|}{ Significance of selected contrasts of treatment effects: } \\
\hline Control versus organic & NS & $* * *$ & $*$ & NS & NS & $* * *$ & NS & $* * *$ & NS & $* * *$ & NS & $* * *$ \\
\hline High versus low & NS & $* *$ & $* * *$ & NS & $* *$ & $* * *$ & NS & $* * *$ & NS & $* * *$ & $* * *$ & NS \\
\hline Feed $B$ versus $C$ & NS & $* * *$ & $* * *$ & NS & $* * *$ & $* * *$ & NS & $* * *$ & NS & $* * *$ & $* *$ & $* * *$ \\
\hline Yard waste versus mush & NS & NS & NS & NS & NS & $* * *$ & NS & $* * *$ & NS & $* * *$ & $* * *$ & $* * *$ \\
\hline
\end{tabular}

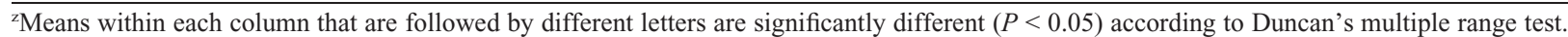
NS, *, **, ***Nonsignificant or significant at $P \leq 0.05, P \leq 0.01$, or $P \leq 0.001$, respectively.

in minerals as well as organic materials. The bulk density (but not waterholding capacity) was also somewhat higher in the feed $\mathrm{C}$ treatment. The difference in yield deserves further investigation.

Growing greenhouse organic tomatoes in a substrate such as peat would ideally rely only on the addition of "dry" ingredients such as compost and gypsum without the need for supplemental liquid nutrition. One disadvantage of organic liquid fertilizers is that they can be much more expensive than conventional fertilizers and therefore may be prohibitively expensive for some greenhouse operations. They are also difficult to administer because of issues such as plugging of drippers, so a greater reliance on the dry components is preferable. However, a typical North American greenhouse tomato crop is 10 months in duration (Anonymous, 1996), and it is important to determine how long the compost can sustain growth. Hence, the purpose of the first experiment was to evaluate the longevity of various composts in supplying two key (and often limiting and expensive) minerals, $\mathrm{N}$ and $\mathrm{P}$. In the first experiment, organic feed $\mathrm{B}$ produced significantly higher yield than did organic feed A. This is because organic feed A was comprised only of $\mathrm{K}, \mathrm{Ca}, \mathrm{Mg}$, and $\mathrm{SO}_{4}$ with no $\mathrm{N}$, $\mathrm{P}$, or micronutrients. The plants were therefore dependent on the composts as sources of these missing elements. However, composts generally are not high in total nutrients and they are only slowly released. The data show that none of the composts, in combination or incorporated at concentrations of up to $40 \%$, were sufficient to supply plant demands for these elements over the 3-month experiment.

In the second experiment, like in the first, the type of compost had no effect on total yield. It is likely that both composts became equally depleted in minerals over the long term. Although compost type had no effect on marketable or total yield in the second experiment, mushroom compost did produce lower weight of unmarketable fruit than did the YW compost treatment. Because most of the unmarketable fruit was downgraded as a result of blossom end rot, this difference could be the result of the higher $\mathrm{Ca}$ levels found in the mushroom compost treatment. As pointed out earlier, mushroom substrate contains gypsum and therefore may be a convenient medium with which to supplement organic substrates with $\mathrm{Ca}$.

In the second experiment, the high concentration of both organic feeds did not produce a corresponding increase in yield (marketable or total) compared with the low concentration. In fact, yields were lower, most likely as a result of the high incidence of fusarium crown and root rot almost exclusively found in those treatments $(92 \%$ of all diseased plants). The incidence of disease was not associated with any particular compost or type of nutrient feed, indicating that these materials were not the source of inoculum. Previous studies of the use of composts for suppression of diseases of containerized plants have frequently observed negative relationships between indicators of substrate biological activity (for example, FDA hydrolysis or $\beta$-glucosidase activity) and root rot diseases (Borrero et al., 2004; Hoitink and Boehm, 1999). Our FDA data are not consistent with those previous observations, because high gross biological activity was associated with treatments that had high disease incidence. However, our findings agree with those of Ntougias et al. (2008) who recently observed that FDA hydrolysis and $\beta$-glucosidase activity were not related to suppression of root diseases caused by Phytophthora nicotianae and Fusarium oxysporum f.sp. radicis-lycopersici. They also found that although $P$. nicotianae was suppressed by all composts tested, fusarium suppression was compost-specific and suggested that compost-related suppression of fusarium crown rot of tomato is the result of complex interaction of biotic and abiotic factors, including the presence of specific antagonists. Borrero et al. (2004) did not observe any relationship between EcoLog parameters and incidence of fusarium crown and root rot. In our study, EcoLog substrate diversity was lower in those treatments with fusarium crown and root rot. Compostrelated suppression of fusarium crown and root rot has been related to increased substrate $\mathrm{pH}$ and $\mathrm{Ca}$ availability (Borrero et al.,
2004). In our study, substrate $\mathrm{pH}$ was slightly lower in the high-concentration organic feeds and therefore may have contributed to the high incidence of fusarium. However, there was no clear relationship between $\mathrm{Ca}$ and disease incidence. The physical characteristics (waterholding capacity, bulk density, and organic matter content) of the substrate were not altered by the high organic feed concentrations compared with the low and so could not be factors in the occurrence of fusarium crown and root rot. However, highfeed concentration treatments tended to have the greatest substrate $\mathrm{N}$ content and EC values. Increased substrate-solution EC predisposes tomato to fusarium crown and root rot (Triky-Dotan et al., 2005). Similarly, increased plant $\mathrm{N}$ status has been associated with increased disease susceptibility, but the relationship is complicated and deserves additional study (Huber and Thompson, 2007); there were no treatment effects on leaf tissue $\mathrm{N}$, although root $\mathrm{N}$ content was not measured. Solutions to the problem of fusarium in organic systems include grafting onto fusarium-resistant rootstock (as was done in our first experiment) or, because yield was optimized at a much lower nutrient feed concentration, avoiding high nutrient concentrations and high substrate EC values.

In our second experiment, the fruit from the hydroponic control had a higher decay index than those of the organic treatments indicating a generally better shelf life in the organic tomatoes. However, there was a positive relationship between decay index and yield when data from all treatments were combined. This indicates a negative relationship between fruit yield and fruit quality, a commonly observed phenomenon (Dorais et al., 2001; Guichard et al., 2001). Hence, the higher quality (lower postharvest decay) in organic treatments could be the result of reduced yield rather than some direct effect of organic growing.

The microbiological activity (FDA values and nematode counts) in the organic treatments were significantly higher than that of the hydroponic treatment. However, the catabolic physiological profile based on the diversity of substrates used by the bacterial 
component was not different. To the best of our knowledge, this is the first time comparisons of substrate microbial activity between organic and hydroponic systems have been reported. One of the underlying philosophies of organic growing stipulates that a biologically active substrate must be present. We have demonstrated that organic systems indeed have greater biological activity than hydroponic systems but they are not necessarily more biologically diverse. In comparing low and high organic feed concentrations, high concentrations sometimes resulted in higher microbiological activity and greater microbivorous nematode counts, but in some cases, there was no effect. It can be assumed that the applied compost and organic feed in our study resulted in greater availability of nutrients for microbial growth. Similar observations have been found by Alvarez et al. (1995), in which the application of compost to soil increases the incidence of bacteria in the tomato rhizosphere, and by Chang et al. (2007), in which the population of bacteria, actinomycetes, and fungi in the soil amended with compost were significantly higher than the populations in the chemical fertilizer treatment and nonfertilized control.

Because organic production systems depend on mineralization of nutrients from organic substrates, they are more dependent on soil biological activity than are conventional hydroponic production systems in which plant-available forms of $\mathrm{N}$ and $\mathrm{P}$ are supplied in the form of soluble chemical fertilizers. Consequently, we hypothesized that mineralization of macronutrients would be the primary factor limiting yields in organic treatments and that measurements of gross biological activity (FDA activity, microbivorous nematode numbers), which are indicative of gross nutrient mineralization, would be correlated with yields across the range of organic treatments. Nematode abundance was highly correlated with FDA activity, which is indicative of total microbial activity (sum of bacteria and fungi). The nematode assemblage was dominated by bacterivorous and fungivorous nematodes, and their abundance reflects production and turnover of both bacteria and fungi. We found that FDA activity was positively correlated with tomato yield in the first experiment but negatively in the second, even when fusarium-contaminated treatments were removed from the analysis. High soil or substrate soil biological activity can be associated with nutrient immobilization when substrate $\mathrm{C} / \mathrm{N}$ ratios are greater than $\approx 20$ (Paul and Clark, 1996). However, all composts used in these experiments had $\mathrm{C} / \mathrm{N}$ ratios less than 15 and none of the organic substrate mixes had $\mathrm{C} / \mathrm{N}$ ratios greater than $\approx 19$ by the end of the trial. In fact, the lowest yields in the second experiment were in the high-feed treatments, which tended to have the lowest final substrate $\mathrm{C} / \mathrm{N}$ ratios of the organic substrate mixes. Furthermore, given the high frequency of fertigation (in all treatments), $\mathrm{N}$ immobilization was not likely to be a yield-determining factor in the hydroponic control, which showed the highest $\mathrm{C} / \mathrm{N}$ ratio. It is also possible that the relationship between biological activity (mineralization) and yield was obscured by other compost or organic feedrelated factors that affect plant growth differently from soil microbial activity such as EC or physical properties as discussed subsequently.

The physical and chemical characteristics of the substrate can potentially affect plant yield and microbial activity. For example, bulk density must be considered in mixing organic components. In this study, organic treatments generally showed increased substrate bulk density compared with the hydroponic treatment with the YW treatments being the highest. These changes are likely the result of decreasing organic matter in the order of hydroponic $>$ mushroom $>$ YW. Organic treatments also showed reduced waterholding capacity compared with the hydroponic treatment. However, the frequent irrigation schedule that we used, typical of commercial greenhouses, would likely minimize any influence of changes in substrate waterholding capacity. The EC of the composts could also be a factor. In the first experiment, the high EC of the swine compost (likely the result of high $\mathrm{K}$ and sodium), even when mixed at the relatively low concentration of $20 \%$, may have influenced the plants, which showed curling in the upper leaves possibly as a result of salinity stress. In the second experiment, the EC of the substrates measured before, during, and after the experiment was not excessive. Nevertheless, higher EC may have contributed marginally to the lower yields of the organic compared with the hydroponic treatment and to the lower yields of the high compared with the low feed concentrations, perhaps by predisposing the plants to fusarium crown and root rot (Dorais et al., 2001; Triky-Dotan et al., 2005). The relationships among substratesolution EC, fusarium, and yields in the context of organic production practices deserves additional study.

Although the fish-based feed (feed C) contributed substantially more $\mathrm{P}$ to the substrate than did the plant-based feed (feed B) over time, the effects on plant $\mathrm{P}$ status (as measured in leaves) were not as great and likely not to affect yields. However, high $\mathrm{P}$ values in the substrate could perhaps limit Ca availability through precipitation reactions. The sustainability of long-term (yearly) additions of high$P$ feeds could not be determined in this study. Boron and $\mathrm{Mn}$ were two of the more variable mineral elements in both substrate and leaf tissue, but no symptoms of deficiency or toxicity were observed in any of the treatments.

\section{Conclusions}

Compost derived from either YW or swine manure, along with supplemental organic $\mathrm{Ca}$, $\mathrm{K}, \mathrm{Mg}$, and $\mathrm{SO}_{4}$, in a peat-based organic mix was insufficient to maintain a greenhouse tomato crop for more than 1 month without showing visible tissue nutrient deficiencies and reduced yield. A supplemental fish-based or plant-based liquid feed containing $\mathrm{N}$ and $\mathrm{P}$ was necessary for adequate growth of a longterm crop. The best organic combination for maximum yield was $50 \%$ compost from either YW or mushroom substrate in combination with a low concentration of liquid feed derived from plant sources. Those yields were as high as those obtained from a conventional hydroponic regimen. In terms of postharvest fruit quality, the decay index was generally lower in the organic treatments than in the hydroponic control. Interestingly, a higher concentration of either fish-based or plant-based liquid organic feed caused proliferation of fusarium crown and root rot, which severely reduced yield. The high incidence of fusarium crown and root rot was not related to physical characteristics of the substrate. The microbiological activity measured as FDA, EcoLog values, and nematode counts were significantly higher in the organic treatments than in the hydroponic treatment, and nematode abundance was often positively correlated with FDA activity.

\section{Literature Cited}

Abbasi, P.A., K.L. Conn, and G. Lazarovits. 2004. Suppression of Rhizoctonia and Pythium damping-off of radish and cucumber seedlings by addition of fish emulsion to peat mix or soil. Can. J. Plant Pathol. 26:177-187.

Albiach, R., R. Canet, F. Pomares, and F. Ingelmo 2000. Microbial biomass content and enzymatic activities after the application of organic amendments to a horticultural soil. Bioresour. Technol. 75:43-48.

Alvarez, M.B., S. Gagne, and H. Antoun. 1995. Effect of compost on rhizosphere microflora of the tomato and on the incidence of plant growth-promoting rhizobacteria. Appl. Environ. Microbiol. 61:194-199.

Anonymous. 1996. Greenhouse vegetable production guide for commercial growers. British Columbia Ministry of Agriculture and Food, Victoria, Canada.

Ball, A.S., D. Shah, and C.F. Wheatley. 2000. Assessment of the potential of a novel newspaper/horse manure-based compost. Bioresour. Technol. 73:163-167.

Borrero, C., M.I. Trillas, J. Orbovas, J.C. Tello, and M. Aviles. 2004. Predictive factors for the suppression of fusarium wilt of tomato in plant growth media. Phytopathology 94:10941101.

Celik, I., I. Ortas, and S. Kilic. 2004. Effect of compost, mycorrhiza, manure and fertilizer on some physical properties of a Chromoxerert soil. Soil Till. Res. 78:59-67.

Chang, E.-H., R.-S. Chung, and Y.-H. Tsai. 2007. Effect of different application rates of organic fertilizer on soil enzyme activity and microbial population. Soil Sci. Plant Nutr. 53:132-140.

Cheng, J., T.E. Shearin, M.M. Peet, and D.H. Willits. 2004. Utilization of treated swine wastewater for greenhouse tomato production. Water Sci. Technol. 50:77-82.

Chong, C. 2005. Experiences with wastes and composts in nursery substrates. HortTechnology 15:739-747.

Chong, C. and F.M. Purvis. 2004. Nursery crop response to substrates amended with raw mill sludge, composted paper mill sludge and composted municipal waste. Can. J. Plant Sci. 84:1127-1134.

del Amor, F.M. 2007. Yield and fruit quality response of sweet pepper to organic and mineral 
fertilization. Renew. Agr. Food Syst. 22: 233-238.

Dorais, M., A.P. Papadopoulos, and A. Gosselin. 2001. Influence of electric conductivity management on greenhouse tomato yield and fruit quality. Agronomie 21:367-383.

Forge, T. and J. Kimpinski. 2007. Nematodes, p. 415-425. In: Gregorich E.G. and M.R. Carter (eds.). Soil sampling and methods of analysis. 2nd Ed. CRC Press, Boca Raton, FL.

Government of British Columbia. 2007. Organic matter recycling regulation. 29 Apr. 2009. $<$ http://www.env.gov.bc.ca/epd/epdpa/mpp/ omrreg.html>.

Green, V.S., D.E. Stott, and M. Diack. 2006. Assay for fluorescein diacetate hydrolysis activity: Optimization for soil samples. Soil Biol. Biochem. 38:693-701.

Guichard, S., N. Bertin, C. Leonardi, and C. Gary. 2001. Tomato fruit quality in relation to water and carbon fluxes. Agronomie 21:385-392.

Heeb, A., B. Lundegårdh, T. Ericsson, and G.P. Savage. 2005. Effects of nitrate-, ammonium-, and organic-nitrogen-based fertilizers on growth and yield of tomatoes. J. Plant Nutr. Soil Sci. 168:123-129.

Heeb, A., B. Lundegårdh, G. Savage, and T. Ericsson. 2006. Impact of organic and inorganic fertilizers on yield, taste, and nutritional quality of tomatoes. J. Plant Nutr. Soil Sci. 169:535-541.

Herencia, J.F., J.C. Ruiz-Porras, S. Melero, P.A Garcia-Galavis, E. Morillo, and C. Maqueda. 2007. Comparison between organic and mineral fertilization for soil fertility levels, crop macronutrient concentrations, and yield. Agron. J. 99:973-983.

Hoitink, H.A.J. and M.J. Boehm. 1999. Biocontrol within the context of soil microbial communities: A substrate-dependent phenomenon. Annu. Rev. Phytopathol. 37:427-446.
Huber, D.M. and I.A. Thompson. 2007. Nitrogen and plant disease, p. 31-44. In: Datnoff, L.E., W.H. Elmer, and D.M. Huber (eds.). Mineral nutrition and plant disease APS Press, American Phytopathological Society, St. Paul, MN.

Kannangara, T., R.S. Utkhede, J.W. Paul, and Z.K Punja. 2000. Effects of mesophilic and thermophilic composts on suppression of Fusarium root and stem rot of greenhouse cucumber. Can. J. Microbiol. 46:1021-1028.

Lee, J.J., R.D. Park, Y.W. Kim, J.H. Shim, D.H. Chae, Y.S. Rim, B.K. Sohn, T.H. Kim, and K.Y. Kim. 2004. Effect of food waste compost on microbial population, soil enzyme activity and lettuce growth. Bioresour. Technol. 93:21-28.

Liedl, B.E., M. Cummins, A. Young, M.L. Williams, and J.M. Chatfield. 2004. Liquid effluent from poultry waste bioremediation as a potential nutrient source for hydroponic tomato production. Acta Hort. 659:647-652.

Litterick, A.M., L. Harrier, P. Wallace, C.A. Watson, and M. Wood. 2004. The role of uncomposted materials, composts, manures, and compost extracts in reducing pest and disease incidence and severity in sustainable temperate agricultural and horticultural crop production-A review. Crit. Rev. Plant Sci. 23:453-479.

Mäder, P., A. Fließbach, D. Dubois, L. Gunst, P. Fried, and U. Niggli. 2002. Soil fertility and biodiversity in organic farming. Science 296:1694-1697.

Marinari, S., G. Masciandaro, B. Ceccanti, and S. Grego. 2000. Influence of organic and mineral fertilisers on soil biological and physical properties. Bioresour. Technol. 72:9-17.

Martínez, F., S. Castillo, S. Pérez, E. Carmona, J. Ordovás, and M. Avilés. 2005. Effect of different soilless growing systems on biological properties of growth media in strawberry. Acta Hort. 697:417-423.
Mazuela, P., M.C. Salas, and M. Urrestarazu. 2005. Vegetable waste compost as substrate for melon. Commun. Soil Sci. Plant Anal. 36: 1557-1572.

Noble, R. and E. Coventry. 2005. Suppression of soil-borne plant diseases with composts: A review. Biocontrol Sci. Technol. 15:3-20.

Ntougias, S., K.K. Papadopoulou, G.I. Zervakis, N. Kavroulakis, and C. Ehaliotis. 2008. Suppression of soil-borne pathogens of tomato by composts derived from agro-industrial wastes abundant in Mediterranean regions. Biol. Fertil. Soils 44:1081-1090.

Paul, E. and F.E. Clark. 1996. Soil microbiology and biochemistry. Academic Press, San Diego, CA.

Rippy, J.F.M., M.M. Peet, F.J. Louws, P.V. Nelson, D.B. Orr, and K.A. Sorensen. 2004. Plant development and harvest yields of greenhouse tomatoes in six organic growing systems. HortScience 39:223-229.

Schnürer, J. and T. Rosswall. 1982. Fluorescein diacetate hydrolysis as a measure of total microbial activity in soil and litter. Appl. Environ. Microbiol. 43:1256-1261.

Smith, D.C., V. Beharee, and J.C. Hughes. 2001. The effects of composts produced by a simple composting procedure on yield of swiss chard (Beta vulgaris L. var. flavescens) and common bean (Phaseolus vulgaris L. var. nanus). Sci. Hort. 91:393-406.

Triky-Dotan, S., U. Yermiyahu, J. Katan, and A. Gamliel. 2005. Development of crown and root rot disease of tomato under irrigation with saline water. Phytopathology 95:1438-1444.

TMECC. 2009. Test methods for the examination of composting and compost. 29 Apr. 2009. $<\mathrm{http}: / / \mathrm{tmecc}$.org/tmecc/>.

Zinati, G.M. 2005. Compost in the 20th century: A tool to control plant diseases in nursery and vegetable crops. HortTechnology 15:61-66. 